\title{
Puerperal women's perceptions regarding preparation for birth in prenatal care
}

\author{
Percepções de puérperas sobre a preparação para o parto no pré-natal
}

\section{Percepciones de puérperas acerca de la preparación para el parto en la atención prenatal}

\section{Carla Andrea de Brito ${ }^{1}$, Antonia Silvânete Saraiva Silva², Rachel de Sá Barreto Luna Callou Cruz ${ }^{3}$, Sarah de Lima} Pinto $^{4}$

Objective: to understand the perception of puerperal women regarding preparation for birth in the prenatal period. Methods: qualitative and exploratory research, undertaken in a maternity unit with 30 puerperal women. The technique of semistructured interview was applied and the discourses were analyzed using the Discourse of the Collective Subject. Results: it was evidenced that the puerperal women perceive the preparation for birth as important for experiencing labor and childbirth. At the time of labor, the fear of the pain was the most frequent feeling. It was identified that preparation for the birth is limited to the passing on of information regarding signs and symptoms which indicate labor as they occur. Conclusion: the professional who assists the pregnant woman must have a broad view regarding her needs, indicating a need for continuing education.

Descriptors: Prenatal Care; Health Education; Labor, Obstetric.

Objetivo: compreender a percepção de puérperas sobre a preparação para o parto no pré-natal. Métodos: pesquisa qualitativa e exploratória, realizada em uma maternidade com 30 puérperas. Aplicou-se a técnica da entrevista semiestruturada e os discursos foram analisados utilizando o Discurso do Sujeito Coletivo. Resultados: evidenciaram que as puérperas percebem a preparação para o parto como importante para a vivência do trabalho de parto e parto. No momento do trabalho de parto, o medo da dor foi o sentimento mais frequente. Identificou-se que a preparação para o parto se limita ao repasse pontual de informação de sinais e sintomas que indicam o trabalho de parto. Conclusão: o profissional que assiste essa gestante deve ter um olhar amplo às suas necessidades, sinalizando necessidade de uma educação continuada.

Descritores: Cuidado Pré-Natal; Educação em Saúde; Trabalho de Parto.

Objetivo: comprender la percepción de puérperas en la preparación para el parto en la atención prenatal. Métodos: estudio exploratorio cualitativo, realizado en una sala de maternidad con 30 puérperas. Aplicada técnica de entrevista semiestructurada y discursos fueron analizados a través del Discurso del Sujeto Colectivo. Resultados: las puérperas percibían la preparación para el parto como importante para la experiencia del trabajo de parto y parto. En el momento del parto, el miedo al dolor era el sentimiento más común. Se encontró que la preparación para el parto se limita a la transferencia puntual de información de signos y síntomas que indican el trabajo de parto. Conclusión: el profesional que asiste a esta mujer embarazada debe tener mirada amplia a sus necesidades, lo que indica necesidad de educación continua.

Descriptores: Atención Prenatal; Educación en Salud; Trabajo de Parto.

\footnotetext{
${ }^{1}$ Secretaria de Saúde do Município de Saboeiro. Saboeiro, CE, Brazil.

${ }^{2}$ Secretaria de Saúde do Município de Exú. Exú, PE, Brazil.

${ }^{3}$ Instituto de Medicina Integral Professor Fernando Figueira. Recife, PE, Brazil.

${ }^{4}$ Universidade Regional do Cariri. Juazeiro do Norte, CE, Brazil. 


\section{Introduction}

Prenatal care is considered an indicator for the quality of the care provided to the woman in the reproductive process, and is reflected in the rates of maternal morbidity and mortality ${ }^{(1)}$. In the Brazilian scenario, much effort has been dedicated to reorganizing the care, formally linking the prenatal care to the birth and puerperium, broadening women's access and ensuring quality through the undertaking of a minimum set of procedures, based on the Humanization of Prenatal and Birth Program ${ }^{(2)}$.

As a result, the number of prenatal consultations grows each year. In 2003, 8.6 million prenatal consultations were held, while in 2009 there were 19.4 million. The increase was of $125 \%$ in this period, being related to the increase in the number of Family Health teams, which went from 19,000 in 2003 to 30,300 in 2009 - and to the consequent increase in the population covered, which grew from $35 \%$ to $50 \%$ in the same period ${ }^{(3)}$.

In spite of the increase in the number of consultations, there are many situations which are not in conformity with the criteria established by the Ministry of Health ${ }^{(4)}$, using as a parameter the analysis regarding the quality of the prenatal consultation subsequent to the implantation of the Humanization of Prenatal and Birth Program, which did not demonstrate advances such as broadening in the prenatal coverage $\mathrm{e}^{(5)}$.

When evaluated through indicators of results, the prenatal care still has shortcomings ${ }^{(6)}$.Although the prenatal coverage has improved considerably, including since the implantation of the Family Health Strategy teams, with the principles and challenges indicated at the time of the proposal of the Program for Integral Attention to Women's Health, the high levels of maternal deaths continue, putting in questionthe quality of the prenatal consultations ${ }^{(7)}$.

One of the actions undertaken in the prenatal consultation which is capable of reflecting qualitative aspects of this program is the educational practices, which should take place throughout the pregnancy, involving the woman and her family members, the aim being to demystifyprejudices and construct new concepts. The undertaking of these activities during all stages of the gravido-puerperal cycleis essential; however, it is in the prenatal phase that the woman must be advised such that she may be able to prepare herself for experiencing birth and the puerperium positively, have fewer risks of puerperal complications, and greater success in breast-feeding ${ }^{(8)}$.

The pregnant woman needs to share the history and perceptions, be embraced holistically by the institution which provides care such that she may feel strengthened and succeed in constructing a body of knowledge relating to her condition, contributing to a more full and healthy experience of the pregnancy, birth and motherhood ${ }^{(9)}$.

During the prenatal period, the pregnant woman must receive information covering all of the aspects involved in the pregnancy. Specifically, the information directed to labor, which has the aim of preparing her to experience this period, which is permeated by feelings such as fear and anxiety ${ }^{(5)}$.

Among the different ways of undertaking the education work, emphasis is placed on group discussions and dramatizations for facilitating the exchanging of experiences. The groups may be undertaken as a way of complementing the attendance provided in the consultations, improving the women's adherence to healthy habits, and reducing anxieties and fears relating to the period of pregnancy and puerperal period $^{(5,9)}$ as well as increasing the possibility of success in breast-feeding ${ }^{(10)}$.

Educational actions do not serve only for the time in question, but also enrich their experiences, forming social networks, used and remembered for the pregnant woman's entire life ${ }^{(9)}$.

Labor and childbirth represent the imminence of the baby's arrival, when anxieties related to the pain, the type of birth and the child's health are present and significantly interfere in the gestational period. As a result, when women are unaware of the information 
regarding the childbirth process, the routine conducts of the maternity center and the place where the birth will take place, they feel very anxious, with fear of the occurrences to come, feelings which make the process highly traumatic ${ }^{(11)}$.

It may be understood that educational actions during the prenatal period have failed should the woman with a low risk pregnancy, attending the consultations, arrive at the last month demonstrating a lack of knowledge regarding the changes arising from her pregnancy and lack of preparation for experiencing the birth ${ }^{(8)}$.

Based on the above, this study aimed to understand the perception of puerperal women regarding preparation for childbirth undertaken during the prenatal care.

\section{Method}

This study is descriptive and exploratory, and uses the qualitative method. It was undertaken in the municipality of Juazeiro do Norte, a city located in the south of the state of Ceará, part of the Micro-region of Cariri, and part of the Metropolitan Region of Cariri.

Data collection took place in a public municipal maternity hospital of Juazeiro do Norte. This hospital has 70 obstetric beds, divided into 35 for clinical obstetric cases and 35 for surgical obstetric cases, being a referral center for a further two municipalities, Caririaçu and Granjeiro, it also has 10 neonatal intensive care beds and 14 beds for neonatal intermediate care. This maternity center was chosen because it has a mean annual number of vaginal births of 1,586 , and a monthly mean of 156 .

The participants in the study were women who had given birth vaginally up to 24 hours previously, and who met the inclusion criteria of being over 18 years of age and having undertaken a minimum of six prenatal consultations, considering the recommendations of the Ministry of Health.

Data collection was finalized when data saturation was achieved. Semistructured interviews were held containing guiding questions, so as to respond to this study's question of concern: "How did puerperal women perceive or assess their preparation for birth, undertaken in the prenatal care?". This was preceded by a structured questionnaire for characterizing the participants.

Prior to data collection a pre-test was undertaken with four puerperal women so as to improve the instrument. Data were analyzed using the Discourse of the Collective Subject analysis technique $^{(12)}$, which consists of providing greater reliability to the information obtained, which ensures quality to the content, thus making it possible to distinguish the development and social representation of the "collective I".

Construction of the discourses took place through identifying the Key-expressions and their Central Ideas. Based on the identification of these elements, a Discourse of the Collective Subject was formed for each question, identified in ascending order using Roman numerals (DCS I, DCS II, DCS III, etc.).

The collective discourse is a synthesis of the collective, written in the first person singular, and made up through the Key expressions and central ideas, aiming to show the opinion or idea of various persons on a specific issue, condensed into a single thought, taking into consideration the coherence in the union of the discourses, the original and specific positioning of that issue and taking into account the criterion of distinction when one question presents more than one response ${ }^{(12)}$.

The study was approved by the Ethics Committee of the Regional University of Cariri, under protocol 32/2010.

\section{Results}

Interviews were held with 30 women aged below 20 years old (8), between 20 and 30 years old (16) and between 30 and 40 years old (6). Regarding educational level, seven women had not completed 
basic education, one had completed basic education, six had failed to complete senior high school, fourteen had completed senior high school, and just one had higher education.

Of the women, 16 were married, seven were in stable relationships, and seven were single. Fifteen women had a family income of one minimum salary, nine women had a family income of two minimum salaries, and four women's family income was below one minimum salary; one woman had no fixed family income, and one had an income equal to three minimum salaries. On average they undertook 7.7 consultations. Of the women, 18 were primiparous, and 12 were multiparous.

Figures 1, below, present the questions, central ideas and the 11 discourses which originated based on the material for analysis.

\begin{tabular}{|c|c|c|}
\hline Question & Central Idea & Discourse of the Collective Subject \\
\hline \multirow{2}{*}{$\begin{array}{l}\text { For you, what does } \\
\text { preparation for the birth } \\
\text { mean? }\end{array}$} & $\begin{array}{l}\text { Preparation is the time in which one } \\
\text { acquires information regarding birth(CI I). }\end{array}$ & $\begin{array}{l}\text { Preparation is giving everybody instruction about all the pros } \\
\text { and cons for each option for birth, talking about how it should } \\
\text { be or will be,and also labor. It guides you so you can get better } \\
\text { organized for what is going to happen (DCS I). }\end{array}$ \\
\hline & $\begin{array}{l}\text { Preparation for the birth is important, but } \\
\text { in practice it doesn't happen (CI II). }\end{array}$ & $\begin{array}{l}\text { They should explain how it is going to be better, because they } \\
\text { only explain that normal birth is good and that after you won't } \\
\text { feel anything, but they should have explained it better (DCS II). }\end{array}$ \\
\hline \multirow[t]{2}{*}{$\begin{array}{l}\text { What information did you } \\
\text { receive regarding labor and } \\
\text { birth during pregnancy? } \\
\text { At what point did you } \\
\text { receive this information? }\end{array}$} & $\begin{array}{l}\text { Information regarding contractions, loss } \\
\text { of fluids and breaking of the membranes. } \\
\text { At the end of the prenatal care (CI III). }\end{array}$ & $\begin{array}{l}\text { Symptoms, for example, if the waters break or loss of fluids. } \\
\text { Losing a sort of liquid like catarrh, with or without blood.They } \\
\text { explained that contractions could be like pain at the bottom of } \\
\text { your tummy, or lower back painpulling downwards, or when you } \\
\text { go to defecate, the tummy becomes hard and then you would } \\
\text { count the contractions when they are at twenty minute intervals, } \\
\text { then at ten minute intervals, and then the person has to go to the } \\
\text { maternity center. At the end of my prenatal care, and the last } \\
\text { consultations, she told me (DCS III). }\end{array}$ \\
\hline & I didn't receive information (CI IV). & $\begin{array}{l}\text { They didn't say anything, they told me that I already knew more } \\
\text { or less, because I had had other children (DCS IV). }\end{array}$ \\
\hline \multirow{3}{*}{$\begin{array}{l}\text { What was the source of } \\
\text { the information that you } \\
\text { received? }\end{array}$} & Family (CI V). & $\begin{array}{l}\text { The information that I got came more from family members. My } \\
\text { mom cleared up many of my doubts now and then she would say } \\
\text { something, she guided me and explained things directly. My sister } \\
\text { told me a lot of things that she had learned in her pregnancy, } \\
\text { people always need the opinion of a mother, of a sister (DCS V). }\end{array}$ \\
\hline & $\begin{array}{l}\text { Friends, colleagues, neighbors who } \\
\text { already had this experience (CI VI). }\end{array}$ & $\begin{array}{l}\text { Other mothers, colleagues, the neighbors who had already gone } \\
\text { through this told me how it would be, each one had their own } \\
\text { way of explaining birth, each one has had different experiences } \\
\text { (DCS VI). }\end{array}$ \\
\hline & $\begin{array}{l}\text { The professional who undertook the } \\
\text { prenatal care(CI VII). }\end{array}$ & $\begin{array}{l}\text { In the health clinic wherel did the prenatal care during the } \\
\text { consultations (DCS VII). }\end{array}$ \\
\hline \multirow{2}{*}{$\begin{array}{l}\text { What was the importance } \\
\text { of this information for your } \\
\text { birth? }\end{array}$} & $\begin{array}{l}\text { Having information would help at the time } \\
\text { of the birth (CI VIII). }\end{array}$ & $\begin{array}{l}\text { When you don't have any information you feel like you are lost in } \\
\text { the desert, you don't know what is going to happen or if you are } \\
\text { doing things correctly, you don't know anything. The information } \\
\text { reduces the anxiety you feel a little ...It helps you not to sit there } \\
\text { thinking, and maybe you don't feel such fear (DCS VIII). }\end{array}$ \\
\hline & Enrich the knowledge (CI IX). & $\begin{array}{l}\text { I think it is important, because if you have doubts, they are } \\
\text { cleared up... It is good for you to find out about other things as } \\
\text { well, such as breast-feeding, and postpartum care. (DCS IX). }\end{array}$ \\
\hline \multirow[t]{2}{*}{$\begin{array}{l}\text { What feelings did you expe- } \\
\text { rience during pregnancy in } \\
\text { relation to the birth? }\end{array}$} & $\begin{array}{l}\text { Fear of the pain and complications } \\
\text { resulting from the birth (CI X). }\end{array}$ & $\begin{array}{l}\text { Fear of the pain, that's the first thought. I was also scared of } \\
\text { something going wrong with me, I don't know, something going } \\
\text { wrong, and me becoming ill and not surviving the birth and } \\
\text { dying, and my baby having to live alone without me. I was also } \\
\text { scared of something happening to my baby (DCS X). }\end{array}$ \\
\hline & $\begin{array}{l}\text { Anxiety and anticipation for getting to } \\
\text { know the child (CI XI). }\end{array}$ & $\begin{array}{l}\text { Anxiety and expectations. I was looking forward to having her } \\
\text { soon. I felt curiosity about seeing the baby, and finding out if she } \\
\text { was perfect (DCS XI). }\end{array}$ \\
\hline
\end{tabular}

Figure 1 - Central ideas and discourses of the collective subjects of the puerperal women regarding preparation for childbirth 


\section{Discussion}

Exchanging knowledge about the types of birth, and their advantages and disadvantages, as well as signs of labor, were indicated by the pregnant women as fundamental in their preparation for labor and birth $^{(13)}$. The first discourse of the collective subject raises the concept that preparation for the birth is when one acquires information regarding the development of the labor and birth. The interviews also list the need to provide guidance regarding each type of birth, their advantages and disadvantages, such that in this way the women may have the knowledge for understanding the period which they are experiencing. In this sense, the understanding of the subject would serve to assist them throughout the process, as a facilitating guide for birth, giving the women confidence in this period of their lives.

The educational action undertaken during the prenatal care, aiming to prepare the pregnant woman for the moment of birth, is fundamental such that she may be strengthened and may conduct the pregnancy and birth with greater autonomy. The data found in this study reflect this anxiety on the part of the puerperal women for knowledge, with a view to them preparing themselves to experience birth and empowering them to participate actively throughout the process.

In the second central idea, the women understand the preparation for labor and birth as an activity which is inherent to the prenatal consultations; however, they confirm the little information they receive in this aspect during the consultations as well as those related to cesarean sections.

The preparation for the birth increases the pregnant women's knowledge and competences, and facilitates the choice of healthy alternatives for experiencing the process of birth and overcoming limitations, and leads to lower risks of being subjected to cesareans and the women's greater satisfaction with the experience of giving birth. Participating in a pregnant women's group evidences the need to reflect upon conflicts which are inherent to the process, as well as ways of overcoming these, reflecting upon and discussing real situations, including among these an approach to the cesarean and its indications ${ }^{(13)}$.

The third discussion, which relates to the information received regarding labor and birth during the pregnancy, shows that the puerperal women received guidance on the breaking of the membranes, loss of the mucus plugand contractions. In the case of the contractions, they explained their characteristics and relate these to the need to defecate. When asked about the time at which they receive this information, the answer was that it happened at the end of the prenatal care.

The information transmitted during the prenatal care covers the beginning of labor and the point at which the pregnant woman should seek hospital attendance. The importance is emphasized of the woman in the prenatal period receiving information regarding the Braxton Hicks contractions, which are painless in the majority of cases but which are perceptible to the pregnant woman, which appear at the end of the pregnancy, but which do not indicate that labor is beginning ${ }^{(5)}$. The occurrence of these contractions can give the false impression that the pregnant woman is going into labor, resulting in pointless visits to the maternity center causing a feeling of frustration.

The moment chosen for passing on this information is generally at the end of the prenatal care, supporting what is stipulated by the Ministry of Health ${ }^{(5)}$. Taking into account the amount of information to be assimilated by the pregnant women, as well as their varying degree of comprehension, the woman in the prenatal period must begin this activity soon after the beginning of the third trimester. It is worth emphasizing that, in the discourses, information was not identified referring to going into labor, but only to how it is identified.

Guidance on birth, breast-feeding and the right to a companion during birth, as well as regarding which maternity center the pregnant woman should 
go to, were also mentioned in small proportions in other studies $^{(14-16)}$.

The pregnant women who arrive at the maternity center not having received information during the prenatal period regarding the process of labor will certainly present fear at the time of giving birth to their child, will not know what attitude to take regarding what they are feeling, and may show resistance to the actions stipulated by the obstetric literature ${ }^{(2,5)}$, such as walking, change of position, ingestion of liquids and relaxing one's muscles, which - if adopted - assist in the process of labor.

In this regard, it is necessary to take a broader view in undertaking the prenatal care, such that information on the birth process may be present in the educational actions so as to give the women the necessary support for experiencing the time of birth without the insecurity that permeates the actions when one faces something unknown ${ }^{(13,17-18)}$.

The fourth discourse (CI-IV did not receive information) evidences that the educational actions related to the preparation for the birth were not undertaken by the woman in the prenatal period, possibly as it was considered that, as some puerperal women were multiparous, the same had already received information on the issue during previous pregnancies, ignoring the need to review the knowledge and add to it. On the one hand, this shows the professional who believes that women who have previously given birth possess the necessary knowledge for facing the process of birth and on the other, the pregnant women who believe that they have the knowledge on the topic.

It is necessary to overcome the false understanding that multiparous women, as they have experienced birth before, may be excluded from the educational process. This process is valuable in the sense that it has the power to change or even to consolidate living habits, regardless of parity. In addition to this, it is necessary that women and health professionals should be made aware, and understand, that knowledge is always in the process of construction $^{(17)}$.

In this context, the health professional must be alert to which information is necessary, regardless of the pregnant woman's parity, and that even if she feels she knows, should categorically explain the issues such that she may, based on a previous knowledge, relate to the new information, so that based on this she may shape her behavior during the birth ${ }^{(13)}$.

Of the sources used by the women for acquiring knowledge regarding preparation for the birth, the family is selected as the main one. This fact is shown to be common due to the facility of accessing these people, as well as the bond of confidence which exists in these relationships ${ }^{(19)}$.

Female friends, colleagues and neighbors who have had these experiences tend to share them, understanding the behaviors, weaknesses and emotional ups and downsof the woman giving birth, creating a confidence in something which since ancient times has been surrounded by fear and taboos, mainly related to the pain.

In selecting the health professionals as a source of information, the discourses evidenced the lack of mention of other strategies which the professional could use as educational practice, with predominance of individual guidance.

The quality of the prenatal care is ensured to the extent that the individual consultations are complemented with individual educational actions, in groups and in a union of both, capable of favoring the women in relation to knowledge about their body and understanding of the changes which take place, acting in a more aware and positive manner during their process of pregnancy and birth ${ }^{(16)}$.

Collective discourse VIII, which originated from the question 'What was the importance of this information for your birth?', reveals that the puerperal women understand that the educational actions during the prenatal consultations help to reduce the feelings which interfere at the time of the birth, point to a reduction in the anxiety and greater control over the emotions at the time of the birth. They also 
mentionthat the preparation helps them to develop skills which favor the birth process, and feel more secure throughout the process and present a reduction of fear. The attitudes, the way that the parturient woman uses her body and how she behaves during labor depend on the information received during the prenatal care, on the socioeconomic context, and on her personality ${ }^{(17)}$.

In relation to the question 'What was the importance of this information for your birth?'and Central Idea-IX (Enriching the knowledge), theninthdiscourse expresses the puerperal women's interest in expanding their knowledge in relation to the issue and other topics which directly involve that point in time, such as breast-feeding and postpartum care. The women report the weakness to which they are exposed when they do not know, and show themselves to be open to dialogue: however, they do not report, in this discourse, that the knowledge acquired would facilitate matters at the time of the birth, but merely praisethe meaningful aspects of the learning.

Regarding preparation for the birth, the pregnant woman will tend to consider it important to know what is going to happen with her, with her body, and all the processes and mechanisms in which she finds herself, and through which she will pass. The pregnancy, labor, birth and puerperium are points which have to be understood through appropriate preparation ${ }^{(18)}$. Central idea X (Fear of the pain and the complications of the birth) raises the predominant feeling at the time of the birth, fear, which occupies the woman's mind when she thinks of her labor, and in fearing its complications, such as, for example, death. The woman asks herself whether she will have "strength" for passing through the process of birth, and feels fear for the safety of the life of her child.

The pain during the birth may be increased by measures which iatrogenize it, such as: solitude, immobilization, the abusive use of oxytocins, the Kristeller maneuver, and unnecessary episiotomy and episiorrhaphy, among others ${ }^{(20)}$.

In undertaking the prenatal care, the professional must demystifythe overstatementsrelated to the birth, and must offer information and sufficient preparation such that when the prenatal care comes to its end, the women may be less anxious and fearful in relation to the pain of the birth process. The importance is perceived of discussinglabor and birth, in the prenatal care, in a clear and accurate way, ensuring the humanized character of the care, and avoiding suffering.

The professional may trystrategies so as to assist with the coping with pain on the part of the pregnant woman, such as breathing and relaxation techniques, which were not mentioned at any point of the discourse.

Discourse XI corresponds to the question 'What feelings did you experience during the pregnancy in relation to the birth?'- anxiety and anticipation for getting to know the child being mentioned. These are natural, motherhood being very significant for women. As a result, it is shown to be essential to adopt anapproach in the consultations which motivates the pregnant women to express their feelings and thus to deal with them in a manner which enriches this period.

Ignorance on the part of the pregnant woman and her family members in relation to the process of labor and birth can contribute to the anxiety of the same ${ }^{(19)}$. Therefore, in undertaking appropriate preparation for the birth, resources should be offered for coping with the anxiety of this time.

\section{Final Considerations}

In relation to preparation for birth, the puerperal women perceive that it is the time in which they acquire the knowledge for experiencing labor and birth, and become more familiarized with their role and the team which will assist them, reducing fear and anxiety surrounding this issue. Through this, they understand that the preparation for the moment 
of birth is fundamental such that they may strengthen the pregnancy and birth and undertake it with greater autonomy.

They perceive the preparation as a means of reducing the fears associated with the topic of 'birth', giving them confidence for experiencing birth calmly and tranquilly, which favors the undertaking of labor. They understand that the professionals who undertake the prenatal care must foster this educational practice such that learning may take place, and maintain continuous discussion of this topic during the care. They indicate, moreover, that the guidance is transmitted in the individual consultations, and that they do not use innovative didactic resources.

The information dispensed most in the prenatal consultations refers to the breaking of the membranes, the loss of liquid, loss of the mucus plug, and the contractions, and occurs at the end of the care, close to the birth. It is appropriate that such questions should be worked upon earlier, so as to allow enough time, so that the pregnent women may assimilate the guidance.

\section{Contributions}

Brito CA contributed through the planning of the project, conception, analysis and final editing of the article. Silva ASS contributed through collection and interpretation of the data and elaboration of the article. Cruz RSBLC contributed through planning of the project, guidance, supervision and revision of the article. Pinto SL contributed through planning of the project, analysis and interpretation of the results, guidance, and final approval of the article to be published.

\section{References}

1. Anversa ETR, Bastos GA, Nunes LN, Pizzol TSD. Qualidade do processo da assistência prénatal: unidades básicas de saúde e unidades de Estratégia Saúde da Família em município no Sul do Brasil. Cad Saúde Pública. 2012; 28(4):789800.
2. Victora CG, Aquino EML, Leal MC, Monteiro CA, Barros FC, Szwarcwald CL. Maternal and child health in Brazil: progress and challenges. Lancet. 2011; 377(9780):1863-76.

3. Ministério da Saúde (BR). Boletim epidemiológico: Consultas pré-natais. Brasília: Ministério da Saúde; 2010.

4. Rodrigues EM, Nascimento RG, Araújo A. Prenatal care protocol: actions and the easy and difficult aspects dealt by family health strategy nurses. Rev Esc Enferm USP. 2011; 45(5):1041-7.

5. Ministério da Saúde (BR). Secretaria de Atenção à Saúde, Departamento de Ações Programáticas Estratégicas, Área Técnica de Saúde da Mulher. Pré-natal e puerpério: atenção qualificada e humanizada. Manual técnico. (Série A. Normas e Manuais Técnicos. Série Direitos Sexuais e Direitos Reprodutivos). Brasília: Ministério da Saúde; 2006.

6. Valente MMQP, Freitas NQ, Áfio ACE, Sousa CSP, Evangelista DR, Moura ERF. Prenatal care: a look at the quality. Rev Rene. 2013; 14(2):280-9.

7. Andreucci CB, Cecatti JG. Evaluation of the Program for Humanization of Prenatal and Childbirth Care in Brazil: a systematic review. Cad Saúde Pública. 2011; 27(6):1053-64.

8. Pessoa IN, Menezes ED, Ferreira TF, Dotto LMG, Bessa LF. Percepção de puérperas sobre assistência de enfermagem na gravidez. Ciênc Cuid Saúde. 2009; 8(2):236-41.

9. Neves PR, Salim NR, Soares GCF, Gualda DRM. Experiences of pregnant women in a group: a descriptive study. Online Braz J Nurs [periodico na Internet]. 2013 [cited 2015 Jan 5]; 12(4):862-71. Available from: http://dx.doi.org/10.5935/16764285.20134143

10. Rodrigues AP, Padoin SMM, Paula CC, Guido LA. Factors those influence in self-efficacy of breastfeeding: an integrative review. Rev Enferm UFPE On line. [periódico na Internet]. 2013 [cited 2015 Jan 5]; 7 (n.esp):4144-52. Available from: http://www.revista.ufpe.br/revistaenfermagem/ index.php/revista/article/view/4031/pdf_2700

11. Sodré TM, Bonadio IC, Jesus MCP, Merighi MAB. Necessidade de cuidado e desejo de participação no parto de gestantes residentes em Londrina-Paraná. Texto Contexto Enferm. 2010; 19(3):452-60. 
12. Lefévre F, Lefévre AMC. O discurso do sujeito coletivo: um enfoque em pesquisa qualitativa (desdobramentos). Rio Grande do Sul: Educs; 2005.

13. Zampieri MFM, Gregòrio VRP, Custòdio ZAO, Regis MI, Brasil C. Processo educativo com gestantes e casais grávidos: possibilidade para transformação e reflexão da realidade. Texto Contexto Enferm. 2010; 19(4):719-27.

14. Viellas EF, Domingues RMSM, Dias MAB, Gama SGN, Theme Filha MM, Costa JV, et al. Assistência pré-natal no Brasil. Cad Saúde Pública. 2014; 30(supl.1):85-100.

15. Domingues RMSM, Hartz ZMA, Dias MAB, Leal MC. Avaliação da adequação da assistência pré-natal na rede SUS do Município do Rio de Janeiro, Brasil. Cad Saúde Pública. 2012; 28(3):425-37.

16. Souza VB, Roecker S, Marcon SS. Ações educativas durante a assistência pré-natal: percepção de gestantes atendidas na rede básica de Maringá-PR. Rev Eletr Enf [periódico na Internet]. 2011 [citado 2015 jan 5]; 13(2):199-210. Disponível em: http:// www.fen.ufg.br/revista/v13/n2/v13n2a06.htm
17. Progianti JM, CostaII RF. Práticas educativas desenvolvidas por enfermeiras: repercussões sobre vivências de mulheres na gestação e no parto. Rev Bras Enferm. 2012; 65(2):257-63.

18. Morgado CML, Pacheco COC, Belém CMS, Nogueira MFC. The effect of the variable 'preparation for childbirth' on anticipating the childbirth experience of pregnant women: comparative study. Rev Referência. 2010; 2(12):17-27.

19. Sand ICPV, Girardon-Perlini NMO, Abreu SM. Ansiedade de familiares de parturientes durante o processo de parto. Cienc Cuid Saúde. 2011; 10(3):474-81.

20. Rattner D. Humanização na atenção a nascimentos e partos: breve referencial teórico. Interface Comun Saúde Educ. 2009; 13(supl. 1):595-602. 